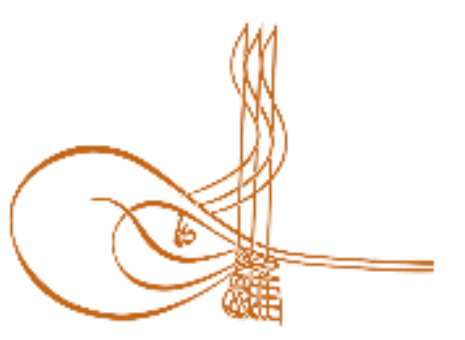

www.turkishstudies.net/turkishstudies
Turkish Studies

eISSN: $1308-2140$

Research Article / Araștırma Makalesi

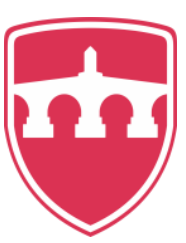

INTERNATIONAL

BALKAN

UNIVERSITY

Sponsored by IBU

\title{
Sınıfında Suriyeli Öğrenci Bulunan Sınıf Öğretmenlerinin İlk Okuma Yazma Sürecine İlişkin Görüşleri*
}

\author{
The Views of Primary School Teachers Who Have Syrian Students in Their Classes About Initial \\ Literacy Process
}

Fatih Mehmet Ciğerci*** - Mesut Yıldırım***

\begin{abstract}
The aim of this research is to determine the opinions of teachers who have Syrian students in their class about the problems experienced during initial literacy teaching process and their suggestions for improving this process. The research was designed in qualitative model and interview method was preferred for data collection in this context. The study group consisted of 10 teachers and interviews were conducted face to face and individually. In the interviews, semi-structured interview form prepared by the researchers was used as data collection tool. In the first stage, the interview form was presented to three experts (1 Turkish education, 1 classroom education and 1 measurement and evaluation specialist). Interviews were recorded with the help of voice recorder and the participants were coded between K1 to K10 before analyzing the data. Descriptive analysis was conducted on the data obtained from the teachers and themes and codes were created within this scope. In the research, it was seen that the data obtained through interviews were collected under two main themes and six sub-themes. The first main theme was focused on the problems experienced by the primary school teachers who have Syrian students in their classrooms during the initial literacy process, and in this context, it was seen that "problems encountered in instruction dimension", "student-originated problems", and "problems arising from social environment" sub-themes emerged. The second main theme focuses on the suggestions of teachers to improve the initial literacy process, and in this context, it was seen that "suggestions on planning", "suggestions for instruction methods, techniques and materials", and "suggestions for teacher education" sub-themes emerged.
\end{abstract}

\footnotetext{
* Bu çalışma 18. Uluslararası Sınıf Öğretmenliği Eğitimi Sempozyumu'nda (USOS 2019) sözlü bildiri olarak sunulmuştur. Çalışma verileri 2019 yılında toplanmıştır.

** Dr. Öğr. Üyesi, Harran Üniversitesi, Eğitim Fakültesi, Temel Eğitim Bölümü

Asst. Prof. Dr., Harran University, Faculty of Education, Department of Basic Education

ORCID 0000-0002-4175-7048

fatihcigerci@harran.edu.tr

**** Dr. Öğr. Üyesi, Harran Üniversitesi, Eğitim Fakültesi, Eğitim Bilimleri Bölümü

Asst. Prof. Dr., Harran University, Faculty of Education Educational Sciences Department

ORCID 0000-0002-4875-2469

mesutyildirim@harran.edu.tr

Cite as/ Atıf: Ciğerci, F. M., Yıldırım, M. (2020). Sınıfında Suriyeli öğrenci bulunan sınıf öğretmenlerinin ilk okuma yazma sürecine iliş̧in görüşleri, Turkish Studies, 15(2), 1541-1555. https://dx.doi.org/10.29228/TurkishStudies.40531

Received/Geliş: 13 January/Ocak 2020

Accepted/Kabul: 25 April/Nisan 2020

Copyright $\mathbb{C}$ MDE, Turkey
} 
Structured Abstract: According to Turkey Humanitarian Situation Report, Turkey is one of the countries which host the most refugees in the world. Considering the total number of refugees in Turkey, it is stated that Syrian refugees (over 3.6 million people) are in the first place and then refugees from Afghanistan, Iraq and Iran have the highest population, respectively (UNICEF, 2019). The fact that there are so many refugees in the country brings with it many problems, especially education. According to the UNICEF (2019) report, the number of Syrian students enrolled in the country is 592.401. Located in the Southeastern Anatolia Region of Turkey, Şanlıurfa hosts the most Syrian refuges after Istanbul, Gaziantep and Hatay (Ministry of Interior, Directorate General of Migration Management, 2020). According to 2019 data, the total number of Syrian students studying in pre-school, primary, secondary and high schools in Şanliurfa is 69,794 (Karademir and Doğan, 2019). Hundreds of thousands of Syrian children continue their education in Turkey. However, in the integration of such a large number of children into the education system, many educational problems have emerged on behalf of both Syrian students and Turkish students, teachers, school administrators and families. For this reason, examining these problems and searching for solution ways are very important for the healthy functioning of the education system.

The aim of this research is to determine the opinions of primary school teachers who have Syrian students in their classes about the problems in the initial literacy process and their suggestions for improving this process. In this context, the sub-problems of the research are determined as follows:

1. What are the opinions of primary school teachers who have Syrian students in their classes about the problems in the initial literacy process?

2. What are the suggestions of primary school teachers who have Syrian students in their classes about the improving initial literacy process?

\section{Method}

The research was designed with case study in qualitative research methods. The participant group consisted of 10 classroom teachers. In the study, criterion sampling method, which is one of the purposive sampling methods, was preferred. The following criteria were taken into consideration in the selection of the participant group:

The participant group;

- are to be among the primary schools in the central districts of Şanlıurfa, where the number of Syrian students is intense,

- are to have classes where at least the half population is composed of Syrian children.

The study group consisted of 10 teachers and interviews were conducted face to face and individually. Interview method, which is one of the qualitative data collection methods, was preferred in the research. In the interviews, semi-structured interview form prepared by the researchers were used as data collection tool. In the first stage, the interview form was presented to three experts (1 Turkish education, 1 classroom education and 1 measurement and evaluation specialist). Interviews were recorded with the help of voice recorder and the participants were coded between K1 to K10 before analyzing the data. Descriptive analysis was conducted on the data obtained from the teachers and themes and codes were created within this scope. The codes were determined separately by the two researchers and then the reliability level of the code analysis was determined with the formula Miles \& Huberman (1994). The consensus was determined in 25 of the total 27 codes, and the difference of opinion was determined in $2(25 /(25+2))$ and within this scope Miles \& Huberman value was calculated as $0.93(\geqq .70)$.

\section{Conclusions and Suggestions}

The data obtained through the interview were evaluated under two main themes within the framework of the sub-problems of the research. It was observed that the codes obtained from the data were collected under six sub-themes within the scope of these two themes. The first main theme is on the "problems experienced by the primary school teachers who have Syrian students in their classes during the initial literacy process" and this theme includes sub-themes of "problems encountered in instruction dimension", "student-originated problems", and "problems arising from social environment". The second main theme is on the "suggestions of the primary school teachers who have Syrian students in their classes to improve the initial literacy process". In this context, the sub-themes of "suggestions on planning", "suggestions for instruction methods, techniques 
and materials", and "suggestions for teacher education" were determined. Within the scope of the theme of "the problems experienced by the classroom teachers who have Syrian students in their class during the initial literacy teaching process"; it was observed that sub-themes of "problems encountered in teaching dimension", "problems originating from students" and "problems originating from social environment" emerged. In the sub-theme of the problems faced in the teaching process, the participants expressed the problems arising from the differences of reading/pronunciation, word-meaning relationship, writing/spelling, speaking and language differences of Syrian students. Under the "student-related problems" sub-theme, such problems as the psychological problems caused by the war in the country of the students since 2011, the problems caused by the age and level differences of the Syrian students in the class compared to the other students, and the neglect and lack of effort that the Syrian students have for school, class and lessons were found. Another result obtained in the study was that Syrian students have problems arising from the social environment like communication problems, family disinterest, social life style and negative perspectives of Turkish families. In the second theme of the research, it was concluded that the participants offered suggestions for planning, suggestions for teaching methods, techniques and materials and suggestions for teacher education under the theme of 'teachers' suggestions to improve the process of initial literacy teaching.

Keywords: Initial literacy education, Syrian students, Teachers' views, Primary school teachers.

Öz: Bu araştırmanın amacı, sınıfında Suriyeli öğrenci bulunan sınıf öğretmenlerinin ilk okuma yazma sürecinde yaşanan problemlere ilişkin görüşlerini ve bu süreci iyileştirmeye yönelik önerilerini belirlemektir. Araştırma nitel modelde desenlenmiş ve bu kapsamda görüşme yöntemi tercih edilmiştir. Çalışma grubu 10 öğretmenden oluşmuş ve öğretmenlerle yapılan görüşmeler yüz yüze ve bireysel olarak gerçekleştirilmiştir. Görüşmelerde veri toplama aracı olarak araştırmacılar tarafindan hazırlanmış yarı yapılandırılmış görüşme formu kullanılmıştır. Çalışma verileri 2019 yılında toplanmıştır. Görüşme formu ilk aşamada üç uzman (1 Türkçe eğitimi, 1 sınıf eğitimi ve 1 ölçme ve değerlendirme alan uzmanı) görüşüne sunulmuştur. Görüşmeler ses kayıt cihazı yardımıyla kaydedilmiş ve verilerin analizinden önce katılımcılar K1-K10 arasında kodlanmıştır. Öğretmenlerden elde edilen veriler üzerinde betimsel analiz gerçekleştirilmiş ve bu kapsamda belirlenen temalar kapsamında kodlar oluşturulmuştur. Araştırmada görüşme yoluyla elde edilen verilerin iki ana tema ve altı alt tema altında toplandığı görülmüştür. Birinci ana temanın, "sınıfında Suriyeli öğrenci bulunan sınıf öğretmenlerinin ilk okuma yazma sürecinde yaşadıkları problemlere" odaklandığ kapsamda "öğretim boyutunda karşılaşılan problemler”, "öğrenciden kaynaklı problemler” ve "sosyal çevreden kaynaklı problemler" alt temalarının ortaya çıktığı görülürken; ikinci ana temanın ise "sınıfında Suriyeli öğrenci bulunan sınıf öğretmenlerinin ilk okuma yazma sürecini iyileştirmeye yönelik önerilerine” odaklandığ1 ve bu kapsamda "planlamaya ilişkin öneriler", "öğretim yöntem, teknik ve materyallerine yönelik öneriler" ve “öğretmen eğitimine yönelik öneriler” alt temalarının ortaya çıktığı görülmüştür.

Anahtar Kelimeler: İlk okuma yazma öğretimi, Suriyeli öğrenciler, Öğretmen görüşleri, Sınıf öğretmenleri.

\section{Giriş}

Milyonlarca insan savaş, ekonomik ve politik problemlerden dolayı ülkelerini terk ederek veya terk etmek zorunda kalarak farklı ülkelere göçmen, mülteci, sığınmacı vb. olarak yerleşmektedir. Birleşmiş Milletler Mülteciler Yüksek Komiserliği raporlarına göre dünyada altmış milyonu aşkın insan ülkelerini terk ederek başka ülkelerde yaşamakta ve UNICEF'in (2019) Türkiye İnsani Durum Raporuna göre dünya genelinde en fazla mülteci ve sığınmaciya ev sahipliği yapan ülkenin Türkiye olduğu (4.007.934 kişi) ifade edilmektedir. Türkiye'deki toplam mülteci ve sığınmacı sayısı ele alındığında ilk sırada Suriyeli (3.6 milyonun üzerinde), ardından ise sirasıyla Afganistan, Irak ve İranlı mülteci ve sığınmacıların en fazla nüfusa sahip oldukları belirtilmektedir.

2011 y1lında Suriye'de başlayan ve halen devam eden iç savaş nedeniyle milyonlarca Suriyeli ülkelerini terk ederek başta Türkiye olmak üzere farklı ülkelere göç etmişlerdir ve bu göç süreci halen de devam etmektedir. Savaşın başladığı ilk günden itibaren Türkiye, Suriyeli mağdur insanlara kapılarını açma politikasını benimsemiş, bu politika sonucunda şu an milyonlarca Suriyeli Türkiye' de yaşamaktadır. Savaşın başlamasının hemen ardından ortaya çıkan göç dalgası ile 2012 
yılı resmi rakamlarına göre Ocak 2012'de Türkiye'ye göç eden kayıtlı Suriyeli sığınmacı sayısı 9.500 iken (UNHCR, 2019), bu say1 04.04.2019 tarihi itibarıla 3.630.767'dir. Diğer taraftan, toplam Suriyeli sayısının yaklaşık 40\%'1 (1,5 milyondan fazla) 0 -18 yaş çocuklardan oluşmaktadır (İçişleri Bakanlığ1 Göç İdaresi Genel Müdürlüğü, 2020).

Ülkede bu denli yoğun mülteci ve sığınmacının olması eğitim başta olmak üzere birçok sorunu da beraberinde getirmektedir. Suriyeli çocukların eğitim hakkından yararlanabilmeleri için bazı önlemler alınmıştır. Çocuklardan bir bölümü barınma merkezlerinde diğer bölümü ise devlet okulları ve geçici eğitim merkezlerinde eğitim hayatlarını sürdürmektedirler. UNICEF (2019) raporuna göre ülke genelinde okullaşan Suriyeli öğrenci sayıs1 592.401'dir. Ancak 400.000'den fazla çocuk tek ebeveynlik, ekonomik acıdan kırılganlık, yüksek hareketlilik, yetersiz bilgilendirme ve yönlendirme, kültürel nedenlerden dolayı eğitim görmemektedir (SETA, 2017). Milli Eğitim Bakanlığı 2014 yılında "Yabancılara Yönelik Eğitim-Öğretim Hizmetleri Genelgesi”ni yayımlamıştır. Genelgede il milli eğitim müdürlerince oluşturulacak komisyonlar tarafindan yabanc1lara yönelik eğitim-öğretim faaliyetleri ve ilgili işlemlerin yürütüleceğini, göçün yoğun olarak yaşandığı illerde ise valilik oluru ile geçici eğitim merkezlerinin oluşturulacağı ifade edilmiştir (MEB, 2014). Diğer taraftan, 2016 yılında MEB Hayat Boyu Öğrenme Genel Müdürlüğü bünyesinde kurulan Göç ve Acil Durum Daire Başkanlığı koordinasyonu ile Suriyelilerin eğitiminin yönetimi yürütülmektedir.

Ülkemizde Güney Doğu Anadolu Bölgesinde yer alan Şanlıurfa, İstanbul, Gaziantep ve Hatay'ın ardından en fazla Suriyeli göçmen ve sığınmayıncaya ev sahipliği yapmaktadır. İlde kayıtlı geçici koruma kapsamındaki Suriyeli sayısı 424.251 'dir ve bu rakam il nüfusunun yaklaşık \%21'ine tekabül etmektedir (İçişleri Bakanlığ1 Göç İdaresi Genel Müdürlüğü, 2020).

MEB 2018-19 Millî Eğitim İstatistiklerine göre, Şanlıurfa ili genelinde ilkokullarda öğrenim gören toplam öğrenci sayısı (resmi ve özel toplamı) 246.673'tür (MEB, 2019). Karademir ve Doğan'ın (2019) yapmış oldukları araştırmaya göre, Şanlıurfa ili genelinde okul öncesi, ilkokul, ortaokul ve liselerde öğrenim gören toplam Suriyeli öğrenci sayısı ise 69.794'tür. Şanlıurfa ilinde öğrenim gören Suriyeli öğrenci sayılarının eğitim kademelerine göre dağılımı Tablo 1'de verilmiştir.

Tablo 1: Şanlıurfa İlinde Eğitim Kademelerine Göre Öğrenim Gören Suriyeli Öğrenci Sayıs1

\begin{tabular}{ccc}
\hline Eğitim Kademesi & $\mathbf{N}$ & \% \\
\hline Okul öncesi ve ilkokul & 46.742 & 66.97 \\
Ortaokul & 17.070 & 24.46 \\
Lise & 5.982 & 8.57 \\
\hline Toplam & 69.794 & 100.00 \\
\hline
\end{tabular}

Tablo 1'deki sayısal veriler ele alındığında okul öncesi ve ilkokullarda öğrenim gören Suriyeli öğrenci sayısı, toplam Suriyeli öğrenci sayının yaklaşık \%67'sini oluşturmaktadır.

Yukarıda verilen sayısal veriler doğrultusunda, yüz binlerce Suriyeli çocuk eğitimlerini ülkemizde sürdürmektedir. Ancak bu kadar fazla sayıda çocuğun eğitim sistemine entegrasyonunda hem Suriyeli öğrenciler hem de Türk öğrenciler, öğretmenler, okul yöneticileri ve aileler adına birçok eğitim sorunu da ortaya çıkmıştır. Suriyeli öğrenciler açısından yaşanılan problemler dikkate alındığında, yapılan çalışmalar başta dil sorunu olmak üzere akademik başarısızlık, iletişim problemleri, adaptasyon sorunları, kültürel farklılıklar gibi sorunların olduğunu ele almışlardır (Belet Boyacı ve Yaşar, 2018; Biçer, Çoban ve Bakır, 2012; Ciğerci ve Güngör, 2016; Güngör, 2015; Güngör ve Şenel, 2018). 
Alanyazında farklı sınıf seviyelerindeki yabancı uyruklu öğrencilerin Türkçe öğrenme sürecinde yaşadıkları sorunlarla ilgili yapılan diğer çalışmalar incelendiğinde, birtakım problemlerin öne çıktığı görülmüştür. Buna göre yabancı uyruklu öğrenciler;

- Türkçeye yeteri kadar hakim olmadıkları için anlama, iletişim, uyum ve kendini ifade edememe sorunları yaşamaktadırlar (Polat, 2012).

- Dil ve kültür farklılığından kaynaklı eğitim-öğretim hayatlarında uyum sağlayamamakta ve iletişim kuramamaktadırlar (Ciğerci ve Güngör, 2016; Güngör, 2015).

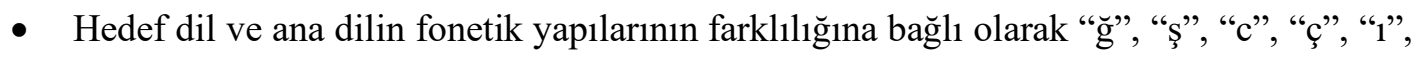
"o", "ö” ve "ü" harflerinin yazımı ve telaffuzunda zorluk yaşamaktadırlar (Açık, 2008; Adalar, 2010; Er, Biçer ve Bozkırl1, 2012).

- Öncelikle yazma ve devamında konuşma, okuma ve dinlemede sorun yaşamaktadırlar (Açık, 2008).

- Türkçe ve Arapça dillerindeki cümle kuruluşu, dil bilgisi (sentaks, semantik vb.) ve morfolojik farklılıklardan dolayı sorun yaşamaktadırlar (Açık, 2008; Adalar, 2010; Candaş Karababa, 2009; Demirci, 2015).

- Türkçe öğretiminde başvurulan dil öğretim metotlarından kaynaklı sorunlar yaşamaktadırlar (Ünlü, 2011).

- Türkçe öğretiminde kullanılan ders materyallerinin eksikliğinden kaynaklanan sorunlar yaşamaktadırlar (Ciğerci ve Güngör, 2016; Er, Biçer ve Bozkırlı, 2012; Ünlü, 2011).

\section{Araştırmanın Amacı}

$\mathrm{Bu}$ araştırmanın amacı, sınıfında Suriyeli öğrenci bulunan sınıf öğretmenlerinin ilk okuma yazma sürecinde yaşanan problemlere ilişkin görüşlerini ve bu süreci iyileştirmeye yönelik önerilerini belirlemektir. Bu kapsamda şu sorulara yanıt aranmıştır?

1. Sınıfında Suriyeli öğrenci bulunan sınıf öğretmenlerinin ilk okuma yazma sürecinde yaşadıkları problemler nelerdir?

2. Sınıfında Suriyeli öğrenci bulunan sınıf öğretmenlerinin ilk okuma yazma sürecini iyileştirmeye yönelik önerileri nelerdir?

\section{Yöntem}

\section{Araştırmanın Modeli}

$\mathrm{Bu}$ araştırma nitel araştırma yöntemlerinden durum çalışması ile desenlenmiştir. Durum çalışması güncel bir durumu içinde bulunduğu gerçek ortamında derinlemesine inceleyen, durumu betimleyip, durumla ilişkili tema ve alt temaları açıklayan nitel bir yaklaşımdır (Creswell \& Poth, 2018; Uçan, 2019; Yin, 2018).

\section{Katılımcı Grup}

Katılımcı grup 10 sınıf öğretmeninden oluşmuştur. Çalışmada amaçlı örnekleme yöntemlerinden ölçüt örnekleme yöntemi tercih edilmiştir. Ölçüt örnekleme, araştırmacının belirli ölçütü ya da ölçütler listesini dikkate aldığı ve belirlenen ölçüt ya da ölçütlere uyan birimlere, örneklem sayısını tamamlayana kadar ulaşmaya çalıştığı örnekleme yöntemidir (Patton, 2005; Yıldırım, 2019; Yıldırım ve Şimşek, 2006). Bu kapsamda katılımcı grubun seçiminde şu ölçütler dikkate alınmıştır: 
Kat1lımc1 grup;

- Şanlıurfa ili merkez ilçelerinde, Suriyeli öğrenci sayısının yoğun olduğu ilkokullar içerisinden,

- Öğrenci sayısının en az yarısı Suriyeli çocuklardan oluşan sınıflarda görev yapan sınıf öğretmenlerinden oluşmuştur.

\section{Verilerin Toplanması}

Araştırmada nitel veri toplama yöntemlerinden görüşme yöntemi tercih edilmiştir. Görüşmenin temel amacı genellikle bir hipotezi test etmekten ziyade, başka insanların deneyimlerini ve bu deneyimleri anlamlandırma biçimlerini ortaya koymaktır (Seidman, 1991). Öğretmenlerle yapılan görüşmeler yüz yüze ve bireysel olarak gerçekleştirilmiştir. Görüşmelerde veri toplama aracı olarak araştırmacılar tarafından hazırlanmış yarı yapılandırılmış görüşme formu kullanılmıştır. Görüşme formu ilk aşamada üç uzman (1 Türkçe eğitimi, 1 sınıf eğitimi ve 1 ölçme ve değerlendirme alan uzmanı) görüşüne sunulmuştur.

Görüşmeler gönüllülük esasına göre gerçekleştirilmiştir. Katılımcıların onayıyla görüşmeler ses kayıt cihazıyla kayıt altına alınmış ve ardından kayıtlar transkribe edilmiştir.

\section{Veri Toplama Aracı}

Araştırmada kullanılan görüşme formu aşağıdaki soruları içermektedir:

- Soru 1: Bir sınıf öğretmeni olarak, Suriyeli çocuklara yönelik ilk okuma yazma öğretiminde ne gibi problemler yaşıyorsunuz?

- Soru 2: Suriyeli öğrencilerle ve aileleriyle iletişimde yaşadığınız problemler nelerdir?

- Soru 3: Hazırlanması muhtemel yeni bir ilk okuma yazma öğretimi programı için "oryantasyon, ön hazırlık, içerik, etkinlikler, materyal, yöntem-teknikler, öğretmen eğitimi, aile katılımı gibi” çeşitli bağlamlarda önerileriniz nelerdir?

- Soru 4: Öğretmenlere yönelik verilmesi muhtemel bir ilk okuma yazma veya Türkçe eğitiminde hangi konularda eğitim almak istersiniz?

\section{Veri Analizi}

Araştırmada verilerin analizinden önce katılımcılar K1-K10 arasında isimlendirilmiştir. Katılımcılardan elde edilen veriler betimsel analiz tekniğiyle çözümlenmiştir. Bu doğrultuda, toplanan verilerden kodlar oluşturulmuş ve belirlenen kodlar önceden belirlenmiş temalar doğrultusunda kategorize edilmiştir.

Kodlar iki araştırmacı tarafından ayrı ayrı belirlenmiş ve ardından Miles \& Huberman (1994) formülüyle kod çözümlemelerinin güvenirlik düzeyi belirlenmiştir. Miles \& Huberman formülü (görüş birliği/(görüş birliği+görüş ayrıllı̆ı)) birden fazla kodlayıcının kodlamaları arasındaki uyumu hesaplamak için kullanılan bir formüldür. Belirlenen toplam 27 kodun 25'inde görüş birliği, 2 sinde ise görüş ayrılığı belirlenmiş $(25 /(25+2))$ ve bu kapsamda Miles \& Huberman değeri $0,93(\geqq .70)$ olarak hesaplanmıştır.

\section{Bulgular}

Araştırmada görüşme yoluyla elde edilen veriler araştırmanın alt problemleri çerçevesinde iki tema altında değerlendirilmiştir. Verilerden elde edilen kodların, söz konusu iki tema kapsamında altı alt tema altında toplandığı görülmüştür. 


\section{Sınıfında Suriyeli Öğrenci Bulunan Sınıf Öğretmenlerinin İlk Okuma Yazma Sürecinde Yaşadıkları Problemlere Yönelik Bulgular}

Araştırmanın birinci alt problemine yanıt aramak için oluşturulan 1. tema "Sınıfında Suriyeli öğrenci bulunan sınıf öğretmenlerinin ilk okuma yazma sürecinde yaşadıkları problemler" olarak belirlenmiştir. Bu kapsamda;

Tablo 2: Sınıfında Suriyeli Öğrenci Bulunan Sınıf Öğretmenlerinin İlk Okuma Yazma Sürecinde Yaşadıkları Problemlere Yönelik Öğretmen Görüşleri

\begin{tabular}{llll}
\hline Alt Tema & Kod & f & Katılımcılar \\
\hline \multirow{2}{*}{ Öğretim } & Okuma/Telaffuz & 7 & $\mathrm{~K} 1, \mathrm{~K} 2, \mathrm{~K} 3, \mathrm{~K} 5, \mathrm{~K} 6, \mathrm{~K} 9, \mathrm{~K} 10$ \\
boyutunda & Kelime-anlam ilişkilendirme & 5 & $\mathrm{~K} 1, \mathrm{~K} 2, \mathrm{~K} 5, \mathrm{~K} 8, \mathrm{~K} 9$ \\
karş1laşılan & Yazma/İmla & 4 & $\mathrm{~K} 1, \mathrm{~K} 5, \mathrm{~K} 8, \mathrm{~K} 9$ \\
problemler & Konuşma & 4 & $\mathrm{~K} 2, \mathrm{~K} 4, \mathrm{~K} 5, \mathrm{~K} 10$ \\
& Dil farklılı̆̆ & 3 & $\mathrm{~K} 4, \mathrm{~K} 7, \mathrm{~K} 10$ \\
\hline Öğrenciden & Psikolojik durum & 6 & $\mathrm{~K} 1, \mathrm{~K} 3, \mathrm{~K} 4, \mathrm{~K} 6, \mathrm{~K} 9, \mathrm{~K} 10$ \\
kaynaklı & Yaş/seviye farkl1lı̆̆ & 3 & $\mathrm{~K} 5, \mathrm{~K} 7, \mathrm{~K} 8$ \\
problemler & İlgisizlik/çaba göstermeme & 2 & $\mathrm{~K} 2, \mathrm{~K} 9$ \\
\hline Sosyal & İletişim problemleri & 5 & $\mathrm{~K} 1, \mathrm{~K} 2, \mathrm{~K} 4, \mathrm{~K} 9, \mathrm{~K} 10$ \\
çevreden & Aile ilgisizliği & 4 & $\mathrm{~K} 3, \mathrm{~K} 6, \mathrm{~K} 7, \mathrm{~K} 10$ \\
kaynaklı & Sosyal yaşam biçimi & 4 & $\mathrm{~K} 3, \mathrm{~K} 6, \mathrm{~K} 8, \mathrm{~K} 10$ \\
problemler & Türk ailelerin olumsuz bakış açıları & 2 & $\mathrm{~K} 5, \mathrm{~K} 8$ \\
\hline
\end{tabular}

Tablo 2 incelendiğinde, sınıfında Suriyeli öğrenci bulunan sınıf öğretmenlerinin ilk okuma yazma sürecinde yaşadıkları problemlerin "öğretim boyutunda karşılaşılan problemler, öğrenciden kaynaklı problemler ve sosyal çevreden kaynaklı problemler" olmak üzere üç alt tema altında toplandığ1 görülmektedir. Bu kapsamda öğretmenlerin, öğretim boyutunda karşılaşılan problemlere ilişkin beş kod ürettikleri ve bu kodların sıklık sırasına göre "okuma ( $\mathrm{f}=7$ ), kelime-anlam ilişskilendirme ( $\mathrm{f}=5)$, yazma/imla ( $\mathrm{f}=4)$, konuşma $(\mathrm{f}=4)$ ve dil farklılığı $(\mathrm{f}=3)$ )" problemlerine yönelik olduğu belirlenmiştir. Belirlenen kodlara ilişkin bazı görüşme alıntıları şu şekildedir:

K1: Bazı harflerde dil farkından dolayı sorun yaşıyoruz. Mesela ü harfi Arapça da yok. Onun yerine u diye okuyorlar ya da ö'yü o olarak okuyorlar. (Okuma/Telaffuz)

K8: (...) Tencerenin ne olduğunu bilmeden yazdırmaya çalışmak çok zor oluyor. Hatta soyut kavramların ögretiminde bu iş daha da zorlaşıyor. (Kelime-anlam ilişkilendirme)

K5: (...)Bir de dikte yaparken ünsüzleri yazıyorlar. Mesela kalem dediğinizde klm yazlyorlar. (Yazma/İmla)

K4: Çocuklar yazmayı sökseler bile konuşurken eklerde sıkıntı yaşıyorlar. Çünkü konuşurken "ögretmenim" demiyor mesela "öğretmen" diyor. (Konuşma)

K10: Arapçanın yapısından kaynaklı olarak defter kullanmada sorunlar var. Sondan başlayarak yazmaya başliyorlar. Bu çocuklar aynı zamanda kendi dillerinde eğitim almaya da devam ediyorlar. Aynı şekilde çocuklar tersten (sağdan sola) yazıyorlar. (Dil farklılığı)

Öğretmenlerin, öğrenciden kaynaklanan problemler alt temasına ilişkin üç kod ürettikleri ve bu kodların sıklık sırasına göre "psikolojik durum $(\mathrm{f}=6)$, yaş/seviye farklılığ $1(\mathrm{f}=3)$ ve ilgisizlik/çaba 
göstermeme ( $\mathrm{f}=2)$ " problemlerine yönelik olduğu tespit edilmiştir. Bu üç koda ilişkin örnek görüşme alıntıları aşağıda sunulmuştur:

K6: Türkiye'ye daha erken gelen ailelerde çok savaş psikolojisi yok. Ama yaşayıp gelenlerde bu psikoloji var. Çocuklarda içe kapanıklı var. Travma devam ediyor benim öğrencilerde. Savaş korkusuyla ögrenme güçlüğü yaşıyorlar. (Psikolojik durum)

K5: Aynı babanın farklı eşlerinden eş zamanlı doğan, yani yaşları yakın olan çocuklar var bir sinıfta. Bu çocukların biri anlamiyorsa diğeri de anlayamıyor. Yaşları farklı olan çocuklar da var aynı sinıfta. Bunun nedeni devletten para yardımı alındığını duydukları için yazdırıyorlar çocukları okula. Yaşı büyük olsa da 1. sinıftan başlayan çocuklar var. Bu da sinıf içerisinde daha farklı problemlerin doğmasına yol açıyor. (Yaş/seviye farklılığı)

K9: Okula sonradan gelen öğrenciler var. Okul açıldıktan 1-2 ay sonra gelen. 2 kişi için geriye dönme gibi bir durumum da olmuyor. Yakalamaları için çabalıyorum ama hevesleri de yoksa çok geri kallyorlar. (IIlgisizlik/çaba göstermeme)

Sosyal çevreden kaynaklı problemler alt temasında ise, sınıf öğretmenlerinin dört kod ürettikleri görülmüştür. Bu kodların yine sıklık sırasına göre "iletişim ( $\mathrm{f}=5)$, aile ilgisizliği $(\mathrm{f}=4)$, sosyal yaşam biçimi ( $\mathrm{f}=4$ ) ve Türk ailelerin olumsuz bakış açıları $(\mathrm{f}=2)$ ") problemlerine yönelik olduğu belirlenmiştir. Bu kodlara ilişkin bazı görüşme alıntıları şu şekildedir:

K1: Tercümanlar zaten sinıfa giremiyor. Bir sorunumuz olduğunda onu buluyoruz. Ama o da yeterince Türkçe bilmiyor, anlatamıyoruz derdimizi ona. Arapça bilen bir Rehber hocamız sayesinde iletişim kuruyoruz. O da her zaman müsait olmuyor. (İletişim problemleri)

K3: Aile ilgilenmiyor ki. Evde de zaten Türkçe adina herhangi bir konuşma yok. Evde çocuğun dili gelişsin demiyorlar. Mesela benim 3 tane kardeş olan ögrencim var. Bunlar çaba göstermiyorlar. Ben de velisini çağırayım dedim. Babası geldi sınıfa. Tercüman aracılığıyla anlattım, çaba göstermiyor bunlar dedim. Söylediğime pişman oldum. Çocuğu dövmeye başladı. Yumruk attı. Bir daha da çağırmadım. Ailelere ilgi deyince şiddet anlıyorlar. (Aile ilgisizliği)

K10: Yıllardır burada olanlar da bir arada yaşadıkları için zaten burada da hayatlarını Arapça kullanarak yaşamaya devam ediyorlar. Kendi bakkalları, firınları vs. var. Adam günlük yaşamda Türkçeye ihtiyaç duymuyor ki. (Sosyal yaşam biçimi)

K8: Bazı veliler rica ediyor. Hocam çocuğumu Türk öğrencilerin yanına oturtur musunuz diye. Bizim Türk çocuklar da aileler de çok istemiyorlar. Ancak Suriyeli çocuk başarıliysa aileyi bir nebze ikna edebiliyoruz. (Türk ailelerin olumsuz bakış açıları)

Sınıfında Suriyeli Öğrenci Bulunan Sınıf Öğretmenlerinin İlk Okuma Yazma Sürecini İyileştirmeye Yönelik Önerilerine Yönelik Bulgular

Araştırmanın ikinci alt problemine yanıt aramak için oluşturulan 2. tema "Sınıfında Suriyeli öğrenci bulunan sınıf öğretmenlerinin ilk okuma yazma sürecini iyileştirmeye yönelik önerileri” olarak belirlenmiştir. Bu kapsamda; 
Tablo 3: Sınıfında Suriyeli Öğrenci Bulunan Sınıf Öğretmenlerinin İlk Okuma Yazma Sürecini İyileştirmeye Yönelik Önerileri

\begin{tabular}{|c|c|c|c|}
\hline Alt Tema & Kod & f & Katılımcılar \\
\hline \multirow{7}{*}{$\begin{array}{l}\text { Planlamaya } \\
\text { ilişkin öneriler }\end{array}$} & $\begin{array}{l}\text { Öğretmen eğitiminde niteliğin } \\
\text { artırılması }\end{array}$ & 6 & $\mathrm{~K} 1, \mathrm{~K} 3, \mathrm{~K} 4, \mathrm{~K} 6, \mathrm{~K} 7, \mathrm{~K} 8$ \\
\hline & Aile eğitimlerinin yapılması & 5 & $\mathrm{~K} 3, \mathrm{~K} 4, \mathrm{~K} 5, \mathrm{~K} 8, \mathrm{~K} 10$ \\
\hline & Hizmet içi eğitimlerinin geliştirilmesi & 5 & $\mathrm{~K} 1, \mathrm{~K} 3, \mathrm{~K} 7, \mathrm{~K} 9, \mathrm{~K} 10$ \\
\hline & $\begin{array}{l}\text { Öğrenci mevcutlarının yeniden } \\
\text { düzenlenmesi }\end{array}$ & 4 & $\mathrm{~K} 4, \mathrm{~K} 5, \mathrm{~K} 8, \mathrm{~K} 9$ \\
\hline & $\begin{array}{l}\text { Eğitim kademesinin yeniden } \\
\text { belirlenmesi }\end{array}$ & 3 & $\mathrm{~K} 2, \mathrm{~K} 6, \mathrm{~K} 7$ \\
\hline & Oryantasyon çalışmaları & 2 & K4,K10 \\
\hline & Hazırlık programları & 2 & $\mathrm{~K} 4, \mathrm{~K} 10$ \\
\hline \multirow{4}{*}{$\begin{array}{l}\text { Öğretim yöntem, } \\
\text { teknik ve } \\
\text { materyallerine } \\
\text { yönelik öneriler }\end{array}$} & Görsel ve işitsel ders materyalleri & 8 & $\mathrm{~K} 2, \mathrm{~K} 3, \mathrm{~K} 4, \mathrm{~K} 5, \mathrm{~K} 7, \mathrm{~K} 8, \mathrm{~K} 9, \mathrm{~K} 10$ \\
\hline & Konuşma saatleri & 5 & $\mathrm{~K} 1, \mathrm{~K} 2, \mathrm{~K} 5, \mathrm{~K} 6, \mathrm{~K} 9$ \\
\hline & $\begin{array}{l}\text { Drama gibi uygulama ağırlıklı yöntem } \\
\text { ve teknikler }\end{array}$ & 4 & $\mathrm{~K} 1, \mathrm{~K} 2, \mathrm{~K} 7, \mathrm{~K} 10$ \\
\hline & $\begin{array}{l}\text { Kültür aktarımı ve kaynaştırma } \\
\text { eğitimleri }\end{array}$ & 3 & $\mathrm{~K} 3, \mathrm{~K} 4, \mathrm{~K} 8$ \\
\hline \multirow{4}{*}{$\begin{array}{l}\text { Öğretmen } \\
\text { eğitimine yönelik } \\
\text { öneriler }\end{array}$} & Drama eğitimi & 5 & $\mathrm{~K} 1, \mathrm{~K} 2, \mathrm{~K} 5, \mathrm{~K} 7, \mathrm{~K} 10$ \\
\hline & Kültür aktarımı/öğretimi & 4 & $\mathrm{~K} 2, \mathrm{~K} 3, \mathrm{~K} 4, \mathrm{~K} 8$ \\
\hline & Beden dili eğitimi & 3 & $\mathrm{~K} 6, \mathrm{~K} 8, \mathrm{~K} 9$ \\
\hline & Diksiyon eğitimi & 3 & $\mathrm{~K} 1, \mathrm{~K} 2, \mathrm{~K} 9$ \\
\hline
\end{tabular}

Sınıfında Suriyeli öğrenci bulunan sınıf öğretmenlerinin ilk okuma yazma sürecini iyileştirmeye yönelik önerilerinin sunulduğu Tablo 3 incelendiğinde, önerilerin "planlamaya ilişkin öneriler, öğretim yöntem, teknik ve materyallerine yönelik öneriler ve öğretmen eğitimine yönelik öneriler" olmak üzere üç alt tema altında toplandıkları görülmüştür.

Öğretmenlerin ilk okuma yazma sürecini iyileştirme noktasında planlamaya ilişkin önerileri için yedi kod ürettikleri ve bu kodların sıklık sırasına göre "öğretmen eğitiminde niteliğin artırılması $(\mathrm{f}=6)$, aile eğitimlerinin yapılması $(\mathrm{f}=5)$, hizmet içi eğitimlerinin geliştirilmesi $(\mathrm{f}=5)$, öğrenci mevcutlarının yeniden düzenlenmesi $(f=4)$, eğitim kademesinin yeniden belirlenmesi $(f=3)$, oryantasyon çalışmaları $(\mathrm{f}=2)$ ve hazırlık programları $(\mathrm{f}=2)$ " hususlarına yönelik öneriler olduğu belirlenmiştir. Söz konusu kodlara yönelik bazı görüşme alıntıları aşağıda sunulmuştur:

K4: Bu konuda drama gibi uygulama ağırlıkl yöntemler olsun konuşma eğitimleri olsun oldukça etkili bence. Bu nedenle henüz lisanstayken adaylara bu eğitimlerin daha etkili verilmesi gerekir. (Öğretmen eğitimi)

K3: Önce aileye öğretmek gerekiyor. Sonra çocuğa. Özellikle günlük yaşamda konuşacakları konular üzerine temel ögretimler yapılsın. Ev içerisinde diyalog kursunlar. (Aile eğitimlerinin yapılması)

K9: Anaokulu eğitiminde kaynaşmaya, sosyalleşmeye yönelik hizmet içi eğitimler verilmeli. Sadece sinıf ögretmenlerini değil, okul öncesi ögretmenlerini de programa dahil edilmesi gerekir. (Hizmet içi eğitimlerinin geliştirilmesi)

K8: Her sınıfta 2-3 kişi olsa Türkçe konuşmak için daha çok zorlarlar kendilerini. E sayıca çok olunca Türkçeye ihtiyaç duymuyorlar. Sadece bu bölgeye dağıtılmış bu çocuklar. (Öğrenci mevcutlarının yeniden düzenlenmesi) 
K2: Okul öncesinden başlanarak eğitim verilmeye başlansa bizde çok daha ileri seviyeye gelirler. Temel dil becerilerini okul öncesinde kazandırmalar gerekir. (Eğitim kademesinin yeniden belirlenmesi)

K10: Oryantasyonla ilgili önerim olacak. Mesela kaç tane Suriyeli ögrrenci var bizim okulda 1. sinıfta, 200 diyelim. Gerekli araştırma yapılıp, üniversiteden de destek alınsa, bu ögrencilerin rehabilitasyonuna yönelik, okulu, ögretmene nasıl davranacă̆ını ya da ne tür çalışmalar yapacaklarını öğreten bir oryantasyon yapllabilirse etkili olur. Ama kendi dillerinde olacak bu oryantasyon. (Oryantasyon çalışmaları)

K4: Birinci sinıfa gelmeden önce bir hazırlık programı uygulanabilir. 1-2 dönem gibi. Yani çocukların konuşacağı, motor becerilerinin gelişeceği, şekil, resim gibi temel etkinlikleri içeren. Yazmanin olmadığı ama filmlerle, şekillerle pratik yapacakları bir eğitim. (Hazırlık programları)

Öğretmenlerin, ilk okuma yazma sürecini iyileştirmek için öğretim yöntem, teknik ve materyallerine yönelik önerilerinin dört kod altında toplandığ 1 görülmüştür. Sıklık sırasına göre bu kodların "görsel ve işitsel ders materyalleri $(\mathrm{f}=8)$, konuşma saatleri $(\mathrm{f}=5)$, drama gibi uygulama ağırlıklı yöntem ve teknikler ( $\mathrm{f}=4$ ) ve kültür aktarımı ve kaynaştırma eğitimleri ( $\mathrm{f}=3$ )" şeklinde oldukları tespit edilmiştir. Belirlenen kodlara ilişkin örnek görüşme alıntıları şu şekildedir:

K7: Kaynak kitap olarak şu an bir şey kullanmiyoruz. Olsa çok iyi olur. Materyal desteği, özellikle görsel ağırlıkl, işitsel ağırlıklı, kllavuz kitapların içerisinde CD şeklinde destekler olmall. (Görsel ve işitsel ders materyalleri)

K1: Yeni bir programda konuşma eğitimleri, konuşma sınıfları olmall. Yani bizim Ingilizce öğrenmede yaşadı̆̆ımız en büyük sıkıntı da bu. Grameri öğrenip konuşmayı es geçiyoruz. Yeni program muhakkak buna önem vermeli. (Konuşma saatleri)

K2: Dramanın da etkisi büyük olacaktır. Çocuk konuşma eğitiminde drama yöntemini kullanarak belki keyifli bir öğrenme gerçekleştirecek. (Drama gibi uygulama ağırlıklı yöntem ve teknikler)

K8: Kültür kaynaşmasıyla alakalı bir içerik hazırlanabilir. Bașta bizim ögretmenlere Arap kültürünün ögretimi, tanıtımı yapılabilir. (Kültür aktarımı ve kaynaştırma eğitimleri)

İlk okuma yazma sürecini iyileștirme hususunda öğretmen eğitimine yönelik öneriler alt temasında, öğretmenlerin dört kod ürettikleri ve sıklık sırasına göre bu kodların "drama eğitimi ( $\mathrm{f}=5)$, kültür aktarımı/öğretimi ( $f=4)$, beden dili eğitimi $(\mathrm{f}=3)$ ve diksiyon eğitimi ( $\mathrm{f}=3$ )" şeklinde olduğu belirlenmiştir. Bu kodlara ilişkin bazı görüşme alıntıları aşağıda sunulmuştur:

K5: Dramayla işlenen derslerin oldukça etkili olacağını düşünüyorum. Ama bu noktada öncelikle biz ögretmenlerin bu eğitimi alması gerekir. (Drama eğitimi)

K2: Kültür aktarımı noktasında eğitim almak isterim. (Kültür aktarımı/öğretimi)

K6: Beden diliyle ilgili bir eğitim alabiliriz aslında. Anlayamadı̆̆ımı yerleri beden dilinden çıkarmaya çalışabiliriz belki. (Beden dili eğitimi)

K9: Mesela ben konuşma becerisi anlamında eğitim almak isterdim. (Konuşma/Diksiyon eğitimi) 


\section{Sonuç ve Tartışma}

Sınıfında Suriyeli öğrenci bulunan sınıf öğretmenlerinin ilk okuma yazma sürecinde yaşanan problemlere ilişkin görüşlerini ve bu süreci iyileştirmeye yönelik önerilerini belirlemeyi amaçlayan bu çalışmada, görüşme yoluyla elde edilen veriler, "sınıfında Suriyeli öğrenci bulunan sınıf öğretmenlerinin ilk okuma yazma sürecinde yaşadıkları problemler" ve "sınıfında Suriyeli öğrenci bulunan sınıf öğretmenlerinin ilk okuma yazma sürecini iyileştirmeye yönelik önerileri” temaları altında toplanmıştır.

"Sinıfında Suriyeli öğrenci bulunan sınıf öğretmenlerinin ilk okuma yazma sürecinde yaşadıkları problemler" teması kapsamında; "öğretim boyutunda karşılaşılan problemler", "öğrenciden kaynaklı problemler" ve "sosyal çevreden kaynaklı problemler" alt temalarının ortaya çıktığı görülmüştür. Öğretim boyutunda karşılaşılan problemler alt temasında katılımcılar, Suriyeli öğrencilerin okuma/telaffuz, kelime anlam ilişkisi, yazma/imla, konuşma ve dil farklılığından kaynaklı sorunları dile getirmişlerdir. Bu problemlerin, ana dil ile hedef dil arasındaki dil bilgisi, sentaks, semantik, yazım ve imla gibi farklılıklarından kaynaklandığı söylenebilir. Bu çalışmada elde edilen bulgular alanyazında yapılan çalışmalarla benzerlik göstermektedir Açık (2008), Adalar (2010), Candaş Karababa (2009), Demirci (2015) yabancı uyruklu öğrencilerin Türkçe ve Arapça dillerindeki cümle kuruluşu, dil bilgisi (sentaks, semantik vb.) ve morfolojik farkl1liklardan dolay1 sorun yaşadıklarını ifade etmişlerdir. Ünal, Taşkaya ve Ersoy (2018) tarafından yapılan çalışmada Suriyeli öğrencilerin Türkçe öğrenme süreçlerinde Türkçe cümle yapısının farklı olması, kelimelerin öğrenilememeleri, konuşmakta zorlandıkları, telaffuz sorunu yaşadıklarını dile getirmişlerdir. Benzer şekilde, Arslan (2011), Bölükbaş (2016), Dönmez ve Paksoy (2015) tarafindan yapılan çalışmalarda yabancı uyruklu öğrencilerin Türkçe öğrenirken en çok konuşma becerisinde zorluk yaşadıklarını; Akkaya ve Gün (2016) Arap kökenli öğrencilerle yaptığı çalışmada alfabe farklılığından dolayı öğrencilerin Türkçe öğrenme sürecinde okuma becerilerinde sorun yaşadıklarını belirtmişlerdir.

Araştırmada, "öğrenciden kaynaklı sorunlar" alt teması kapsamında öğrencilerin ülkelerinde 2011 yılından bu zamana süre gelen savaştan kaynaklı psikolojik sorunlar, sınıflardaki Suriyeli öğrencilerin diğer öğrencilere göre yaş ve seviye farklılıklarından kaynaklı sorunlar ve Suriyeli öğrencilerin okul, sınıf ve derslere karşı besledikleri ilgisizlik ve çaba göstermeme gibi olumsuz durumlardan kaynaklı sorunlar yaşadığı sonucuna ulaşılmıştır. Bu bulgulara paralel olarak, Sirin ve Rogers Sirin (2015) tarafından yapılan bir araştırmada Suriyeli mülteci çocukların savaşta aile bireylerinden birilerini kaybettiğini, yaralandığını veya yaralandığını, bu çocukların diğer akranlarına göre çok daha fazla travma ve stres bozukluğu yaşadıklarını; Moralı (2018) Suriyeli çocukların yaşadığı sorunların başında duyuşsal durumlarından kaynaklı sorunların olduğun belirtmiştir. Araştırmada öğrenciden kaynaklı diğer iki sorunun da Suriyeli öğrencilerin ait oldukları sınıftaki diğer öğrencilere göre yaş ve seviye farklılıklarından ve öğrencilerin okul, sınıf ve derslere karşı ilgisizlik ve isteksizliğinden kaynaklı sorunlar olduğudur. Bu bulgulara benzer olarak Bulut, Kanat Soysal ve Gülçiçek (2018) yaptıkları çalışmada sığınmacı öğrencilerin sınıflara yerleştirmedeki ölçütün yaş düzeyi olduğu, ancak seviye farklılıklarından dolayı öğretme-öğrenme sürecinde sorunlar yaşandığını ifade etmişleridir. Diğer taraftan, Moralı (2018), Suriyeli öğrencilerin motivasyon eksikliği ve sorumsuzluk gibi sorunlar yaşadığını belirtmiştir.

Araştırmada ilk okuma yazma sürecinde yaşanan sorunlardan bir diğerinin de sosyal çevreden kaynaklı sorunlar olduğu; bunların başında iletişim problemi, aile ilgisizliği, sosyal yaşam biçimi ve Türk ailelerin olumsuz bakış açıları olduğu sonucuna ulaşılmıştır. Benzer şekilde, Ciğerci ve Güngör' ün (2016); Sarıtaş, Şahin ve Çatalbaş'ın (2016) yaptıkları çalışmalarda öğretmenlerin öğrencilerin ile iletişim kurmada zorlandıklarını belirtmişlerdir. Polat (2012) ise yabancı uyruklu öğrencilerin uyum, okul aile iletişimsizliği ve rehberlik gibi konularda sorun yaşadıklarını tespit etmiştir. Bulut, Kanat Soysal ve Gülçiçek (2018) tarafından yapılan çalışmada, Türk ailelerin 
sınıflarda mülteci çocukların olmasını istemediği ve Suriyeli çocukların ailelerinin okul aile işbirliğine dahil olmaları gerektiği sonucuna varılmıştır.

Araştırmanın ikinci teması olan sınıfında Suriyeli öğrenci bulunan sınıf öğretmenlerinin ilk okuma yazma sürecini iyileştirmeye yönelik önerileri" teması altında katılımcıların planlamaya ilişkin öneriler, öğretim yöntem, teknik ve materyallerine yönelik öneriler ve öğretmen eğitimine yönelik öneriler sundukları sonucuna ulaşılmıştır. Planlamaya ilişkin olarak çalışmada öğretmen eğitiminde niteliğin artırılması, aile eğitimlerinin yapılması, hizmet içi eğitimlerin geliştirilmesi, sınıf mevcutlarının yeniden düzenlemesi, eğitim kademesinin yeniden belirlenmesi, oryantasyon çalışmalarının yapılması ve Suriyeli öğrenciler için hazırlık programlarının yapılması gerektiği sonucuna ulaşılmıştır. Benzer şekilde, Güngör ve Şenel (2018) ve Polat (2012) yabancı uyruklu öğrenciler için ayrı sınıflar açılması gerektiğini; Culbertson ve Constant (2015) da okulların ve öğretmenlerin mülteci çocuklara iyi bir eğitim verebilmeleri için ulusal çapta programlar geliştirilmesi gerektiğini; Boylu ve Işı1k (2019), Koçoğlu ve Yanpar Yelken (2018) öğretmenlere sunulan hizmet-içi eğitim yapılmasına rağmen mevcut eğitimlerin bu eğitimlerin öğretmenlerin ihtiyaçlarını karşılamadığını belirtmiştir.

Çalışmada ortaya çıkan öğretim yöntem, teknik ve materyallerine yönelik öneriler bağlamında ise görsel ve işitsel ders materyallerinin geliştirilmesi, Suriyeli öğrenciler için konuşma saatleri düzenlemesi, farklı yöntem ve teknikler kullanılması ve kültür aktarımı, kaynaştırma eğitimleri verilmesi gerektiği sonucuna varılmıştır. Ayrıca, bu çalışmada sınıfında Suriyeli bulunan öğretmenlere yönelik farklı eğitimlerin (drama, kültür aktarımı, beden dili ve diksiyon eğitimleri) yapılması gerektiği ulaşılan bir diğer sonuçtur. Gün, Kaya ve Yılmaz (2019) çalışmalarının sonucunda özellikle iki kültür arasındaki benzer yönlerin öne çıkarılarak Suriyeli öğrencilerin uyum probleminin önüne geçilmeye çalışılabileceği yönünde öneri sunmuşlardır. Bu öneri, bu çalışmada öğretmenlerin kültür aktarımı konusunda eğitim almak istediklerine yönelik önerileriyle ilişkilendirildiğinde, öğretmenlerin kültürler arasındaki benzerlik ve farklılıklara yönelik alacakları bir eğitim sonrasında Suriyeli öğrencilerin yaşadıkları uyum problemleriyle baş etmeleri noktasında daha donanımlı olabilecekleri düşünülmektedir. Güngör ve Şenel (2018) yaptıkları çalışmada öğrencilerin eğitim-öğretim sürecinde öğrencilerin seviyelerine göre uygun program ve materyal kullanılması gerektiğini; Biçer ve Kılıç (2017) de yaptıkları çalışmada Suriyeli mültecilere Türkçe öğretiminde kullanılan ders kitaplarının öğrenci seviyesine uygun olmadığını; Bulut, Kanat Soysal ve Gülçiçek (2018) öğretmenlerin gerek derslerde kullanmak gerekse sığınmacı çocukların ders dışı etkinliklerde yararlanmasına ve özellikle dil becerilerini geliştirmesine yönelik kaynak sorunu yaşadıklarını belirtmiştir. Arı (2010) kitap etkinliklerinin arttırılması, görsel, işitsel vb. araç-gereç kullanmaya önem verilmesinin gerektiğini vurgulamıştır. Diğer taraftan, Güngör ve Şenel (2018) sınıfında yabancı uyruklu öğrenci bulunan öğretmenlere ikinci dil ve yabancı dil olarak Türkçe öğretimi konusunda kurslar düzenlenmesini ve Boylu ve Işı1k (2019) eğitime başlamadan önce Suriyeli veliler ve öğrencilere Türkçe öğrenmenin gerekliliği hakkında oryantasyon programları düzenlenmesini ve öğretmenlere yönelik düzenlenen hizmetçi eğitimlerin sayısı artırılarak içerikte ise uygulamaya ağırlık verilmesini önermiştir. Son olarak Özer Aytekin ve Sönmez Ektem'in (2019), öğretmen eğitiminde uygulamaya yönelik etkinliklere yer verilmesi gerektiği yönündeki, Eren'in (2019) ise hizmet öncesi ve hizmet içi eğitimler ile öğretmenlerin yabancı çocuklar ile çalışabilecek şekilde yetiştirilmesi gerektiği yönündeki sonuçlarının yine bu çalışma sonuçlarını destekleyici nitelikte oldukları görülmüştür.

\section{Kaynakça}

Açı, F. (2008). Türkiye'de yabancılara Türkçe öğretilirken karşılaşılan sorunlar ve çözüm önerileri. Uluslararası Türkçe Eğitimi ve Öğretimi Sempozyumu'nda sunulan sözlü bildiri. Doğu Akdeniz Üniversitesi Eğitim Fakültesi Türkçe Eğitimi Bölümü, Lefkoşa. 
Adalar, S.D. (2010). TÖMER'de yabancı dil olarak Türkçe öğrenen Arap öğrencilerin kompozisyonlarmda hata analizi. Dil Dergisi, 148, 7-16. https://doi.org/10.1501/dilder_0000000127

Akkaya, A. ve Gün, M. (2016). Araplara Türkçe öğretiminde karş1laş1lan sorunlar: Ürdün örneği. Turkish Studies, 11(19), 9-18. https://doi.org/10.7827/turkishstudies.11231

Arı, Ş. (2010). Kuzey Klbris Türk Cumhuriyeti'nde ilköğretimin ikinci kademesinde öğrenim gören yabancılara Türkçe ögretimi üzerine bir değerlendirme. Doktora Tezi, Gazi Üniversitesi, Eğitim Bilimleri Enstitüsü, Ankara.

Arslan, A. (2011). A new group about teaching Turkish to foreigners: refugees and refugee students. Educational Research and Review, 6(21), 1011-1017. doi:10.5897/ERR11.165

Belet Boyacı, Ş.D. \& Yaşar, E. (2018). Teaching Turkish as a second language to Syrian refugees. Educational Research and Reviews, 13(18), 645-653. https://doi.org/10.5897/err2018.3565

Biçer, N. ve Kılıç, B.S. (2017). Suriyeli öğrencilere Türkçe öğretmek için kullanılan ders kitaplarının öğretmen görüşleri doğrultusunda değerlendirilmesi. Ana Dili Eğitimi Dergisi, 5(4), 649663. https://doi.org/10.16916/aded.329809

Biçer, N., Çoban, İ. ve Bakır, S. (2012). Türkçe öğrenen yabanc1 öğrencilerin karşılaştıkları sorunlar. Uluslararası Sosyal Araştırmalar Dergisi, 7(29).

Boylu, E. ve Işık, P. (2019). Suriyeli mülteci çocuklara yabancı dil olarak Türkçe öğretenlerin yaşadıkları durumlara iliş̧in görüşleri. Gazi Üniversitesi Eğitim Fakültesi Dergisi, 39(2), 895-936. https://doi.org/10.17152/gefad.421069

Bölükbaş, F. (2016). Suriyeli mültecilerin dil ihtiyaçlarının analizi: İstanbul örneği. Journal of International Social Research, 9(46). https://doi.org/10.17719/jisr.20164622571

Bulut, S., Kanat Soysal, Ö. ve Gülçiçek D. (2018). Suriyeli öğrencilerin Türkçe öğretmeni olmak: Suriyeli öğrencilerin eğitiminde karş1laş1lan sorunlar. TEKE-Uluslararası Türkçe Edebiyat Kültür Ë̆itim Dergisi, 7(2), 1210-1238. https://doi.org/10.7884/teke.4179

Candaş Karababa Z.C. (2009). Yabancı dil olarak Türkçenin öğretimi ve karşılaşılan sorunlar. Ankara Üniversitesi Ĕ̈itim Bilimleri Fakültesi Dergisi, 42(2), 265-277.

Ciğerci, F.M. \& Güngör, F. (2016). The problems encountered by the foreign primary school students from the perspectives of classroom teachers: Bilecik sampling. Eğitim ve Gelecek Dergisi, 10, 137-164.

Creswell, J.W. \& Poth, C.N. (2018). Qualitative inquiry and research design: choosing among five approaches $\left(3^{\text {rd }}\right.$ ed.). Thousand Oaks, CA: Sage Publications, Inc.

Culbertson, S. \& Constant, L. (2015). Education of Syrian refugee children: Managing the crisis in Turkey, Lebanon, and Jordan. Santa Monica: RAND Corporation. https://doi.org/10.7249/rr859

Demirci M (2015). B1 seviyesinde Türkçe öğrenen Suriyeli öğrencilerin sesli okuma becerisiyle ilgili tespitler. Turkish Studies, 10(7), 333-358. https://doi.org/10.7827/turkishstudies.8149

Dönmez, M.İ. ve Paksoy, S. (2015). Türkiye'de öğrenim gören Suriyeli öğrencilerin Türkçe öğrenmede karşılaştıkları sorunlar üzerine bir araştırma: Kilis 7 Aralık Üniversitesi örneği. International Journal of Languages' Education and Teaching UDES, 1907-1919. https://doi.org/10.18298/ijlet.366 
Er, O., Biçer, N. ve Bozkırlı, K.Ç. (2012). Yabancılara Türkçe öğretiminde karşılaşılan sorunların ilgili alan yazını ışı̆̆ında değerlendirilmesi. Uluslararası Türkçe Edebiyat Kültür Eğitim Dergisi, 1(2), 51-69.

Eren, Z. (2019). Yönetici ve öğretmen görüşlerine göre göçmen çocukların eğitim sorunları ve çözüm önerileri. Bolu Abant İzzet Baysal Üniversitesi Eğitim Fakültesi Dergisi, 19(1), 213-234. https://doi.org/10.17240/aibuefd.2019.19.43815-476805

Gün, M., Kaya, İ. ve Yılmaz, A. (2019). Geçici eğitim merkezlerinde görev yapan Türkçe okutmanlarının Suriyeli öğrencilere Türkçe öğretimine ilişkin görüşlerinin $\begin{array}{llll}\text { değerlendirilmesi. } & \text { Turkish } & \text { Studies, } & \text { 14(6), }\end{array}$ https://doi.org/10.29228/turkishstudies.39278

Güngör, F. (2015). Yabancı Uyruklu İlkokul Öğrencilerinin Eğitim-Öğretiminde Yaşanan Sorunlara İlişkin Öğretmen ve Öğrenci Görüşleri. Yüksek Lisans Tezi, Anadolu Üniversitesi Eğitim Bilimleri Enstitüsü, Eskişehir.

Güngör, F. ve Şenel, E.A. (2018). Yabancı uyruklu ilkokul öğrencilerinin eğitim - öğretiminde yaşanan sorunlara ilişkin öğretmen ve öğrenci görüşleri. Anadolu Journal of Educational Sciences International, 8(2), 124-173.

İçişleri Bakanlığı Göç İdaresi Genel Müdürlüğü (2020). Göç istatistikleri. https://www.goc.gov.tr/gecici-koruma5638 adresinden 28.01.2020 tarihinde alınmıştır.

Karademir, D. ve Doğan, M. (2019). Suriyeli mültecilerin mekânsal analizi: Şanlıurfa örneği. Coğrafya Dergisi - Journal of Geography, 39, 111-124. https://doi.org/10.26650/jgeog2019-0053

Koçoğlu, A. ve Yanpar Yelken, T. (2018). Suriyeli öğrencilere Türkçe dil becerileri kazandırma sürecinde ilkokul türkçe dersi öğretim programları ile ilgili öğretmen görüşleri. Eğitimde Nitel Araştırmalar Dergisi, $\quad 6(2), \quad$ 131-160. https://dergipark.org.tr/tr/pub/enad/issue/38696/450077 adresinden 10.04.2019 tarihinde alınmıştır. https://doi.org/10.14689/issn.2148-2624.1.6c2s7m

MEB (2014). MEB mevzuat. http://mevzuat.meb.gov.tr/dosyalar/1715.pdf adresinden 08.04.2019 tarihinde erişilmiştir.

MEB (2019). Millî eğitim istatistikleri - örgün eğitim 2018-19. T.C. Millî Eğitim Bakanlı̆̆ı Strateji Geliştirme Başkanlığı, Resmi İstatistik Programı Yayını. http://sgb.meb.gov.tr/meb_iys_dosyalar/2019_09/30102730_meb_istatistikleri_orgun_egiti m_2018_2019.pdf adresinden 28.01.2020 tarihinde alınmıştır.

Miles, M.B. \& Huberman, M.A. (1994). Qualitative data analysis. London: Sage Publication.

Moralı, G. (2018). Suriyeli mülteci çocuklara Türkçenin yabancı dil olarak öğretiminde karşılaşılan sorunlar. OPUS-Uluslararası Toplum Araştırmaları Dergisi, 8(15), 1426-1449. https://doi.org/10.26466/opus.443945

Özer Aytekin, K ve Sönmez Ektem, I. (2019). Sınıflarında bulunan Suriyeli göçmen çocuklar ile ilgili okul öncesi öğretmenlerin görüşlerinin incelenmesi (Hatay ili örneği). Turkish Studies, 14(5), 2557-2580. https://doi.org/10.29228/turkishstudies.32712

Patton, M. Q. (2005). Qualitative research. New York, NY: John Wiley \& Sons, Ltd. 
Polat, F. (2012). Türkiye'de ögrrenim gören yabancı uyruklu ilköğretim öğrencilerinin karşılaştıkları sorunlar ve çözüm önerileri. Yüksek Lisans Tezi, Fırat Üniversitesi, Eğitim Bilimleri Enstitüsü, Elazığ. https://doi.org/10.12739/nwsa.2017.12.4.e0034

Sarıtaş, E., Şahin, Ü ve Çatalbaş, G. (2016). İlkokullarda yabancı uyruklu öğrencilerle karşılaşılan sorunlar. Pamukkale Üniversitesi Sosyal Bilimler Enstitüsü Dergisi, (Ekl), 208-229. https://dergipark.org.tr/tr/pub/pausbed/issue/34754/384374 adresinden 12.05.2019 tarihinde alınmıştır.

Seidman, I., E. (1991). Interviewing as qualitative research: A guide for researchers in education and the social sciences. New York: Teachers College Press.

SETA (2017). Engelleri aşmak: Türkiye'de Suriyeli çocukları okullaştırmak. İstanbul: Turkuvaz Haberleşme ve Yayıncılık A.Ş.

Sirin, S. R. \& Rogers Sirin, L. (2015). The educational and mental health needs of Syrian refugee children. Washington, DC: Migration Policy Institute.

Uçan, S. (2019). Durum çalışması araştırması. Ed. S. Şen \& İ Yıldırım. Eğitimde araştırma yöntemleri içinde, 227-248. Ankara: Nobel Yayınları.

UNHCR (2019). Registered Syrian refugees by date. https://data2.unhcr.org/en/situations/syria/location/113\#_ga=2.33486398.1270410912.1554 720437-668264970.1554720437 adresinden 08.04.2019 tarihinde alınmıştır.

UNICEF (2019). Turkey humanitarian situation report. https://reliefweb.int/sites/reliefweb.int/files/resources/UNICEF\%20Turkey\%20Humanitari an\%20Situation\%20Report\%20-\%20February\%202019.pdf adresinden 08.04.2019 tarihinde alınmıştır.

Ünal, K., Taşkaya, S. M. ve Gürsoy, G. (2018). Suriyeli göçmenlerin yabancı dil olarak Türkçe öğrenirken karşılaştıkları sorunlar ve çözüm önerileri. Ahi Evran Üniversitesi Sosyal Bilimler Enstitüsü Dergisi, 4(2), 134-149. https://doi.org/10.31592/aeusbed.472814

Ünlü, H. (2011). Türkiye'de ve dünyada Türkçenin yabancılara öğretiminde karşılaşılan sorunlar ve çözüm önerileri. Gazi Üniversitesi Türkçe Araştırmaları Akademik Öğrenci Dergisi, 1(1), 108- 116.

Yıldırım, A. ve Şimşek, H. (2006). Sosyal bilimlerde nitel araştırma yöntemleri (5. Baskı). Ankara: Seçkin Yayıncılık

Yıldırım, M. (2019). Örneklem ve örnekleme yöntemleri. Ed. S. Şen \& İ Yıldırım. Eğitimde araştırma yöntemleri içinde, 61-93. Ankara: Nobel Yayınları.

Yin, R. (2018). Case study research and applications $\left(6^{\text {th }}\right.$ Ed.). Thousand Oaks, CA: Sage Publications, Inc. 